\title{
Kinetics of appearance of intestinal lesions in mice mono-associated with a lethal or non-lethal strain of Clostridium difficile
}

\author{
FRANCOISE CASTEX, S. JOUVERT, M. BASTIDE and G. CORTHIER*
}

Unité de Recherche en Immunologie, Faculté de Pharmacie, Université de Montpellier 1, 34060 Montpellier Cedex 1 and * Laboratoire d'Ecologie et de Physiologie du système Digestif, INRA, CRJ, 78350 Jouy-en-Josas, France

\begin{abstract}
Summary. The kinetics of the appearance of intestinal lesions induced by orogastric inoculation of gnotobiotic mice with a lethal strain of Clostridium difficile (VPI) that produced toxins $\mathrm{A}$ and $\mathrm{B}$ in vivo and in vitro was studied and compared with the lesions induced by non-lethal $C$. difficile strain 786 that produced toxins A and B in vitro but only toxin B in measurable amounts in vivo. Different portions of the intestine were removed 12, 20,26 and $30 \mathrm{~h}$ after inoculation and studied by scanning electronmicroscopy. The remaining portions were homogenised for enumeration of $C$. difficile and quantification of toxin $\mathrm{A}$ by enzyme immunoassay and toxin B by cytotoxicity. The results showed that, following inoculation: (i) measurable amounts of both toxins were necessary to produce lesions; (ii) with strain VPI, the caecum and the colon were rapidly impaired and completely destroyed after 1 day, whereas the small intestine was damaged to a lesser extent; (iii) C. difficile strain 786 did not cause mucosal damage but induced mucus-like or serum-like secretion and morphological changes in the caecal enterocytes only.
\end{abstract}

\section{Introduction}

Antibiotic-associated Clostridium difficile enterocolitis is an infectious disease with clinical symptoms ranging from severe colitis to diarrhoea. ${ }^{1}$ Two distinct toxins implicated in the pathogenesis of this disease are produced by $C$. difficile: $:^{2-4}$ toxin A has cytotoxic ${ }^{5}$ and enterotoxic ${ }^{2,6}$ activities and causes fluid accumulation and mucosal damage; toxin $B$ has potent cytotoxic activity and alters the morphology of various cultured cells. ${ }^{2,-11}$ Injection of toxins A and B into the intestine is lethal for rabbits, mice, hamsters and monkeys. ${ }^{12-15}$ Factors such as tissue degradative enzymes or capsule have not been found to correlate with the virulence of C. difficile strains. ${ }^{16,17}$

The lesions induced by $C$. difficile in man can be reproduced in the well-defined gnotobiotic rodent model. ${ }^{18,19}$ In this model, the pathological effects and death are observed only when both toxins are produced. ${ }^{18,19}$ In contrast, $C$. difficile strain 786 , which seems to produce only toxin B in vivo, does not cause the death of gnotobiotic rats and mice. ${ }^{20,21}$ The histopathological lesions in the caecum of mice monoassociated with lethal or non-lethal $C$. difficle strains can be correlated with the severity of the induced disease. $^{21}$

We describe a scanning electronmicroscopy (SEM) study of the kinetics of the appearance of mucosal

Received 19 April 1993; revised version accepted 4 July 1993. lesions produced after intestinal inoculation of C. difficile strain VPI that produces toxins A and B in gnotobiotic mice. We also studied the relationship between the pathology, the topographical histology of the mucosa, the multiplication of the $C$. difficile strain and the amounts of toxins. The results were compared with those obtained under the same conditions with C. difficile strain 786 that does not produce measurable amounts of toxin $\mathbf{A}$ in vivo but produces only toxin $\mathbf{B}$.

\section{Materials and methods}

\section{C. difficile strains}

Strain VPI 10463 (VPI), isolated from an abscess, was provided by N. M. Sullivan, Virginia Polytechnic Institute and State University, Blacksburg, VA, USA $;{ }^{18}$ this strain produced toxins $A$ and $B$ in vivo and in vitro. Strain 786 , isolated from an adult suffering from post-antibiotic colitis was provided by M. Popoff, Institut Pasteur, Paris, France; this strain produced toxins $\mathrm{A}$ and $\mathrm{B}$ in vitro, albeit in lesser amounts than strain VPI. Only toxin B has been detected in vivo. ${ }^{21}$

\section{Experimental schedule and animals}

$\mathrm{C} 3 \mathrm{H} / \mathrm{He}$ axenic mice were reared in Trexler-type isolators (La Calhène, Vélizy, France). They were fed, 

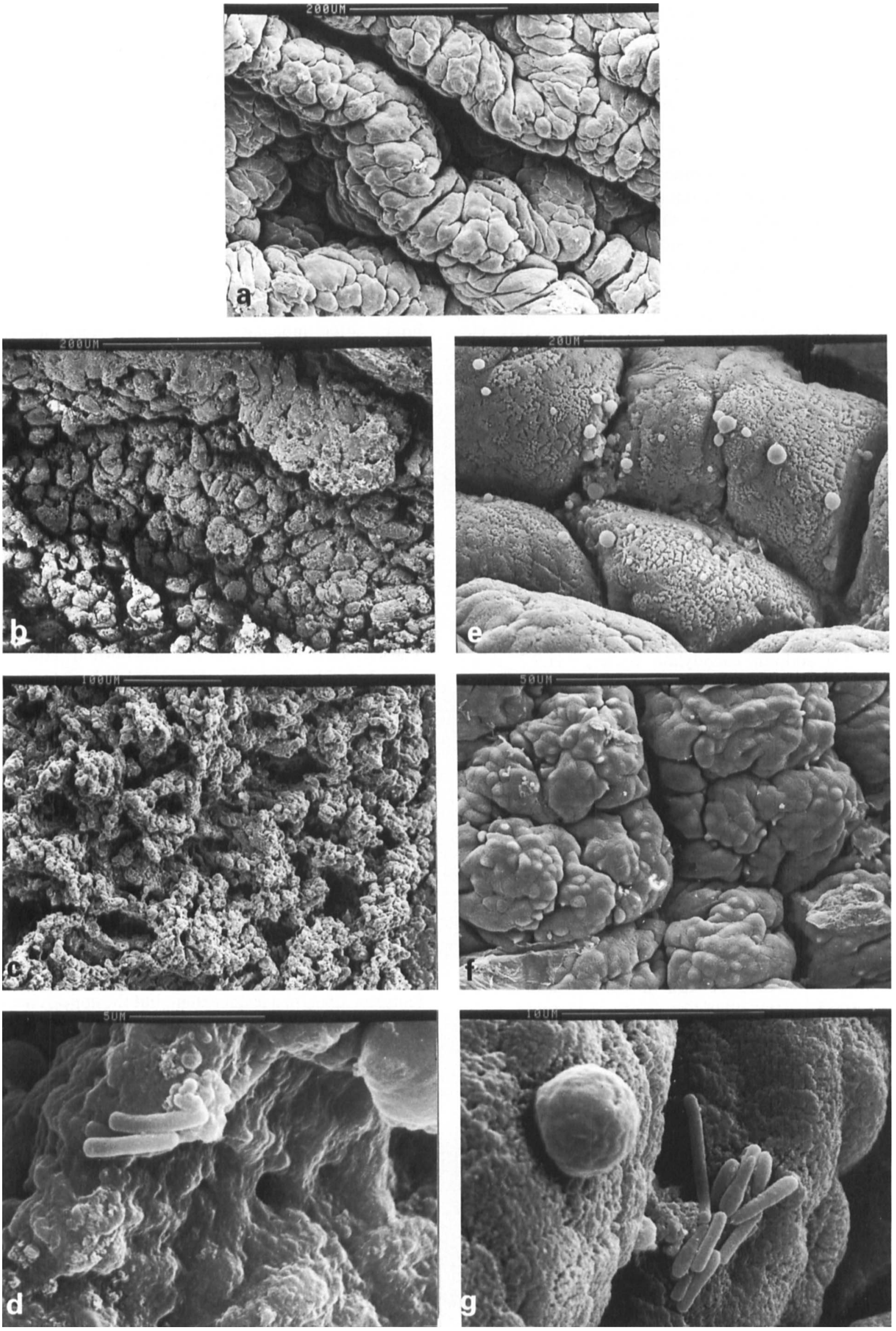

Fig. 1. Scanning electronmicrographs of the caecum of : $\mathbf{a}$, axenic control mice $(\mathrm{bar}=200 \mu \mathrm{m}) ; \mathbf{b}$, mice mono-associated with $C$. difficile strain VPI, $20 \mathrm{~h}$ after inoculation $(\mathrm{bar}=200 \mu \mathrm{m}) ; \mathbf{c}, 26 \mathrm{~h}$ after inoculation $(\mathrm{bar}=100 \mu \mathrm{m}) ; \mathbf{d}, 30 \mathrm{~h}$ after inoculation $($ bar $=5 \mu \mathrm{m}) ; \mathbf{e}$, mice monoassociated with $C$. difficile strain $786,26 \mathrm{~h}$ after inoculation $(\mathrm{bar}=20 \mu \mathrm{m}) ; \mathbf{f}$ and $\mathrm{g}, 30 \mathrm{~h}$ after inoculation (bar $=50 \mu \mathrm{m}$ and $10 \mu \mathrm{m}$ respectively). 
ad libitum, a commercial diet (R03-40, UAR, Villemoisson, France) sterilised by $\gamma$-irradiation.

Three groups of 12 mice, maintained in different isolators, were used. One group was not treated and served as control. The other two groups were inoculated by the orogastric route with $0.5 \mathrm{ml}$ of a fresh culture (c. $10^{8}$ viable bacteria) of $C$. difficile strain VPI or 786. At four different times after inoculation $(12,20$, 26 or $30 \mathrm{~h}$ ), three mice from each group were killed by cervical elongation and the intestinal tracts were removed. The following samples $(0.5 \mathrm{~cm})$ were collected: for scanning electronmicroscopy: duodenum $(0.5 \mathrm{~cm}$ after the pylorus), jejunum $(11 \mathrm{~cm}$ after the pylorus), ileum ( $1 \mathrm{~cm}$ before the caecum), caecum (in the middle) and colon ( $1 \mathrm{~cm}$ after the caecum). The remaining intestinal portions were used for bacteriological counts and toxin assays. They were divided into four samples: duodenum-jejunum (all the duodenum and most of the jejunum), jejunum-ileum (a part of the jejunum and all the ileum), caecum and colon. To avoid non-specific modification of the gut mucosa, intestinal samples were removed only from freshly killed mice.

\section{Scanning electronmicroscopy (SEM)}

The specimens were fixed in glutaraldehyde $1 \% \mathrm{v} / \mathrm{v}$

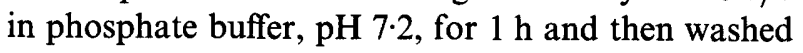
in $0.2 \mathrm{M}$ sodium cacodylate buffer, $\mathrm{pH} 7 \cdot 2$. After stepwise dehydration through a series of graded ethanol solutions, the specimens were coated with gold to a thickness of $c .30 \mathrm{~nm}$ with a Balzers SCD 020 ion sputter and then examined with a Cambridge Stereoscan model 100 scanning electronmicroscope. ${ }^{22}$

\section{Enumerations of $C$. difficile and investigation of toxins}

The samples were weighed and homogenised. Bacterial counts were performed under anaerobic conditions as described previously. ${ }^{23}$ Toxin A was quantified by enzyme immunoassay ${ }^{24}$ and toxin $B$ was determined by tissue culture assay as described previously. ${ }^{23,25}$ Toxin $\mathrm{A}$ and $\mathrm{B}$ concentrations were expressed as $\log _{10} \mathrm{ng} / \mathrm{ml}$ or / $\mathrm{g}$ of gut sample.

\section{Results}

\section{Animal behaviour}

To avoid the natural and non-specific destruction of the intestinal mucosa that occurs after death, we killed the mice and removed their intestines at selected times after inoculation with the bacteria. Mice inoculated with $C$. difficile strain VPI appeared normal up to $26 \mathrm{~h}$; at $30 \mathrm{~h}$, the remaining mice were moribund and would have died from the infection. In contrast, mice inoculated with $C$. difficile strain 786 remained healthy throughout the experimental period.

\section{SEM examinations}

After inoculation with the VPI strain, lesions were observed first in the caecum, then the colon and finally the small bowel, whereas the various parts of the intestinal tract of the mice inoculated with strain 786 showed few morphological changes.

Effects of $C$. difficile strain VPI on the caecum. The caecal mucosa showed signs of impairment $12 \mathrm{~h}$ after inoculation. The voluminous folds observed on control specimens (fig. 1a), were less visible; the enterocytes were spaced further apart and, in some places, cell shedding was evident. Bacteria were detectable on the mucosa, but were not very numerous. Twenty hours after inoculation, the cells were severely damaged (fig. 1b). The bacteria, distributed alone or in groups, were easily detectable. By $26 \mathrm{~h}$ after inoculation with this strain, the caecal folds had disappeared and the mucosa was perforated and had a "chewed" appearance (fig. 1c). The cellular surface was disorganised and covered with debris, probably resulting from the destruction of enterocytes. Bacteria were seen, alone or in groups. The mucosa still had a chewed appearance $30 \mathrm{~h}$ after inoculation; at this time the bacteria were difficult to find (fig. 1d).

Effects of C. difficile strain 786 on the caecum. Twelve and $20 \mathrm{~h}$ after inoculation with this strain, the general aspect of the caecum remained unchanged. The surface of the mucosa was also normal; however, after $20 \mathrm{~h}$, bulges looking like droplets had appeared in a few places on the surface of the enterocytes. By $26 \mathrm{~h}$ after inoculation, the general aspect of the caecal mucosa was normal but the number of droplets had increased (fig. 1e). These droplets were easily recognisable by their compact and rough aspect and seemed to be attached to the surface by thin filaments. At $30 \mathrm{~h}$, some of the enterocytes began to lose their shape and to round up, giving the mucosa a "marblebag" appearance (fig. 1f). Other cells appeared to be shedding and bacteria were distributed in groups (fig. $1 \mathrm{~g}$ ).

Effects of $C$. difficile strain VPI on the colon. When compared to the caecum, the colon showed the same features, albeit to a lesser extent, but the appearance of the lesions was delayed; $20 \mathrm{~h}$ after inoculation, the colonic mucosa was normal and resembled the colon of the control mice (fig. 2a) and some bacteria were visible. At $26 \mathrm{~h}$, the general aspect of the colon was impaired and distinct holes were present in the mucosa (fig. 2b) separated by areas with less damage. Some cells were beginning to be shed and bacteria were easily detectable (fig. 2c). As the time after inoculation increased, the holes, injured areas and number of bacteria seemed to become more numerous.

Effects of $C$. difficile strain 786 on the colon. Inoculation with this strain did not appear to affect the colon. The general aspect of the cellular surface of the mucosa remained normal throughout the sampling period (fig. 2d). The bacteria were heterogenously 

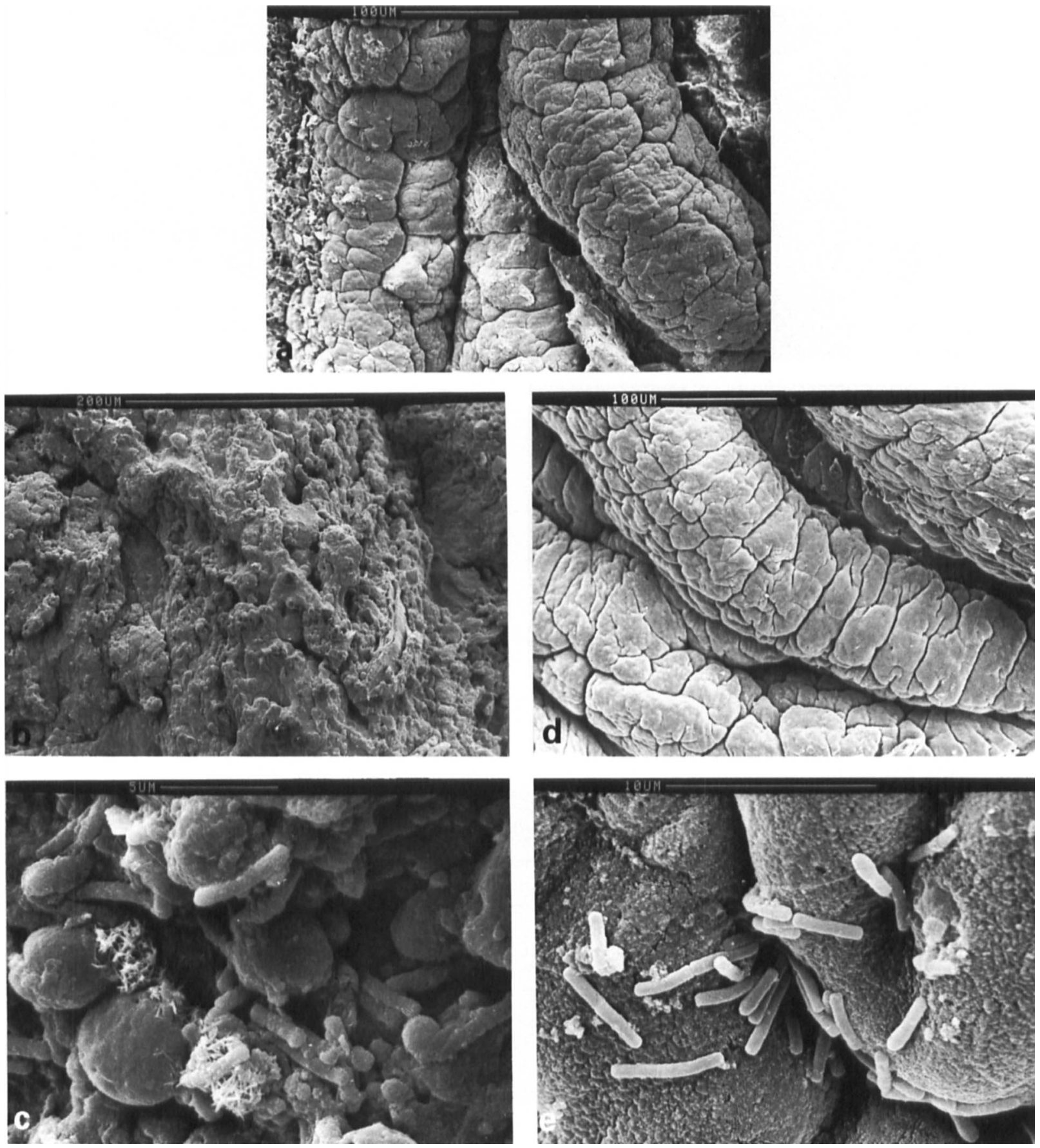

Fig. 2. Scanning electronmicrographs of the colon of: a, axenic control mice (bar $=100 \mu \mathrm{m}$ ); b and c, mice mono-associated with $C$. difficile strain VPI, $26 \mathrm{~h}$ after inoculation (bar $=200 \mu \mathrm{m}$ and $5 \mu \mathrm{m}$ respectively); $\mathbf{d}$ and $\mathbf{e}$, mice mono-associated with $C$. difficile strain 786 , $30 \mathrm{~h}$ after inoculation (bar $=100 \mu \mathrm{m}$ and $10 \mu \mathrm{m}$ respectively).

distributed and were easily visible 20 and $30 \mathrm{~h}$ after inoculation (fig. 2e).

Effects of C. difficile strain VPI on the small bowel. After inoculation with the bacteria, all portions of the small bowel studied showed lesions. In all cases, these lesions were less severe than those observed in the caecum and colon; the villi never disappeared even in the small bowel of moribund mice studied $30 \mathrm{~h}$ after inoculation. It was extremely difficult to locate the bacteria in these samples.

There were differences in the kinetics of appearance of the lesions in the duodenum, the jejunum and the ileum. The general aspects of the duodenal mucosa was similar to that of the controls (fig. 3a); but 12 and $20 \mathrm{~h}$ after inoculation, some villi showed irregular and elongated shapes, and their tips were often broken or punctured with holes. By 26 and $30 \mathrm{~h}$ after inoculation, the duodenal mucosa seemed less damaged; even though the tips of some of the villi remained mishapen, the lesions had disappeared (fig. 3b).

In the jejunum, the effects produced by inoculation with $C$. difficile strain VPI were different. When 

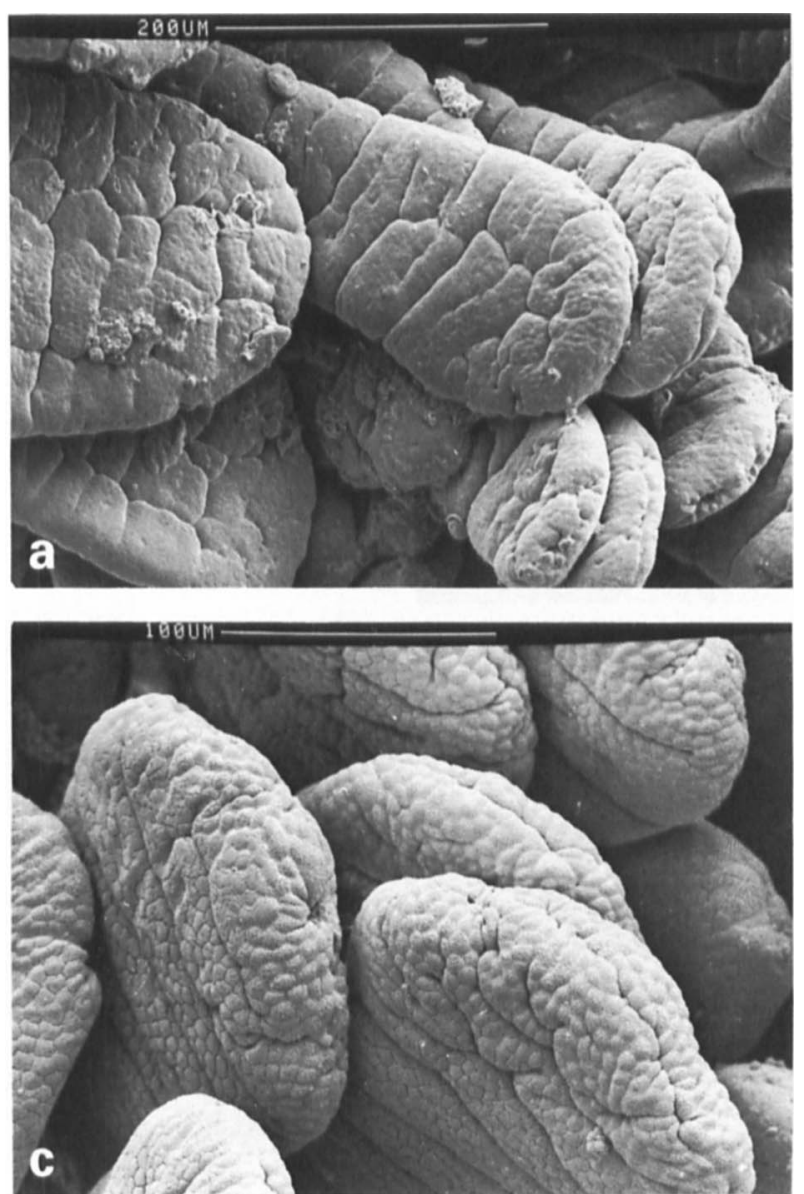

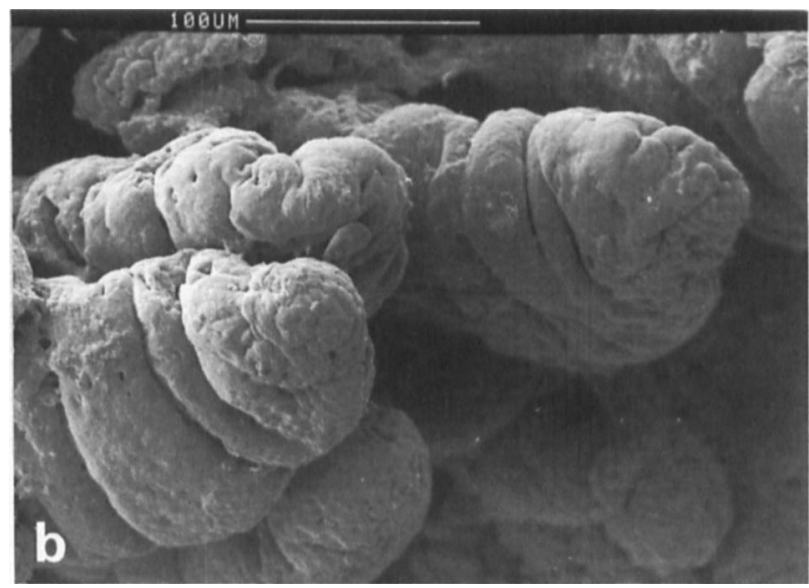

Fig. 3. Scanning electronmicrographs of the duodenum of axenic control mice (bar $=200 \mu \mathrm{m}) ; \mathbf{b}$, mice mono-associated with C. difficile strain VPI, $30 \mathrm{~h}$ after inoculation $(\mathrm{bar}=100 \mu \mathrm{m}) ; \mathrm{c}$, mice mono-associated with $C$. difficile strain $786,30 \mathrm{~h}$ after inoculation (bar $=100 \mu \mathrm{m})$.

Table. Bacterial counts and toxin concentration

\begin{tabular}{|c|c|c|c|c|c|c|c|c|c|c|c|}
\hline \multirow{3}{*}{$\begin{array}{l}\text { Origin of } \\
\text { sample }\end{array}$} & \multirow{3}{*}{$\begin{array}{c}\text { Time (h) } \\
\text { after } \\
\text { inoculation }\end{array}$} & \multicolumn{6}{|c|}{ Strain VPI } & \multicolumn{4}{|c|}{ Strain 786} \\
\hline & & \multicolumn{2}{|c|}{ Viable count } & \multicolumn{2}{|c|}{ Toxin $\mathbf{A}$} & \multicolumn{2}{|c|}{ Toxin B } & \multicolumn{2}{|c|}{ Viable count } & \multicolumn{2}{|c|}{ Toxin B } \\
\hline & & $\underset{(\mathrm{SE})}{\log _{10} / \mathrm{g}}$ & $\begin{array}{l}\text { Mean } \\
\text { (SE) }\end{array}$ & $\underset{\text { (SE) }}{\log _{10} n g / g}$ & $\begin{array}{c}\text { Mean } \\
(\mathrm{SE})\end{array}$ & $\begin{array}{c}\log _{10} \mathrm{ng} / \mathrm{g} \\
\text { (SE) }\end{array}$ & $\begin{array}{l}\text { Mean } \\
(\mathbf{s E})\end{array}$ & $\underset{(\mathrm{SE})}{\log _{10} / \mathrm{g}}$ & $\begin{array}{l}\text { Mean } \\
\text { (SE) }\end{array}$ & $\begin{array}{c}\log _{10} n g / g \\
(\mathrm{SE})\end{array}$ & $\begin{array}{c}\text { Mean } \\
(\mathbf{S E})\end{array}$ \\
\hline Duodenum-jejunum & $\begin{array}{l}12 \\
20 \\
26 \\
30\end{array}$ & $\left.\begin{array}{l}4.7(0.9) \\
4.7(0.4) \\
4.5(0.7) \\
4.3(0.4)\end{array}\right\}$ & $4.5(0 \cdot 6)$ & $\begin{array}{l}\mathbf{N} \\
\mathrm{N} \\
\mathrm{N} \\
\mathrm{N}\end{array}$ & & $\begin{array}{l}\mathrm{N} \\
\mathrm{N} \\
\mathrm{N} \\
\mathrm{N}\end{array}$ & & $\left.\begin{array}{l}4.2(0.9) \\
4.9(0.6) \\
5.5(0.2) \\
5.4(0.2)\end{array}\right\}$ & $5.0(0.5)$ & & \\
\hline Jejunum-ileum & $\begin{array}{l}12 \\
20 \\
26 \\
30\end{array}$ & $\left.\begin{array}{l}4.4(0.2) \\
5.5(0.6) \\
5.6(0.2) \\
5.1(0.6)\end{array}\right\}$ & $5 \cdot 1(0 \cdot 4)$ & & & $\begin{array}{l}\mathrm{N} \\
\mathrm{N} \\
\mathrm{N} \\
\mathrm{N}\end{array}$ & & $\left.\begin{array}{l}5.6(0.6) \\
5.5(0.3) \\
5.9(0.2) \\
5.8(0.1)\end{array}\right\}$ & $5 \cdot 7(0-3)$ & & \\
\hline Caecum & $\begin{array}{l}12 \\
20 \\
26 \\
30\end{array}$ & $\left.\begin{array}{l}8.7(0.2) \\
9.0(0.3) \\
8.0(0.1) \\
7.7(0.3)\end{array}\right\}$ & $8 \cdot 3(0 \cdot 2)$ & $\left.\begin{array}{l}2.5(0.6) \\
2.6(0.7) \\
2.5(0.6) \\
2.6(0.5)\end{array}\right\}$ & $2 \cdot 5(0 \cdot 6)$ & $\left.\begin{array}{l}2.5(0.3) \\
3 \cdot 1(0.2) \\
3 \cdot 1(0.2) \\
2 \cdot 4(0.3)\end{array}\right\}$ & $2 \cdot 7(0 \cdot 2)$ & $\left.\begin{array}{l}7.9(0.2) \\
8.5(0.3) \\
8.5(0.2) \\
8.6(0.1)\end{array}\right\}$ & $8 \cdot 4(0 \cdot 2)$ & $\begin{array}{l}\text { N } \\
0.9(0.1) \\
0.7(0.1)\end{array}$ & \\
\hline Colon & $\begin{array}{l}12 \\
20 \\
26 \\
30\end{array}$ & $\left.\begin{array}{l}9.5(0.6) \\
7.6(0.3) \\
8.0(0.5) \\
8.1(0.2)\end{array}\right\}$ & $8 \cdot 3(0 \cdot 4)$ & $\left.\begin{array}{l}2.5(0.5) \\
2.0(0.7) \\
1.8(0.5) \\
1.9(0.4)\end{array}\right\}$ & $2 \cdot 0(0.5)$ & $\left.\begin{array}{l}2.1(0.3) \\
2.0(0.3) \\
2.6(0.3) \\
2.4(0.2)\end{array}\right\}$ & $2 \cdot 3(0 \cdot 3)$ & $\left.\begin{array}{l}7.3(0.3) \\
7.9(0.4) \\
7.7(0.3) \\
7.9(0.5)\end{array}\right\}$ & $7.7(0.4)$ & $\begin{array}{l}0.2(0 \cdot 1) \\
0.7(0 \cdot 2)\end{array}$ & \\
\hline
\end{tabular}

SE, standard error. ND, not detected $-<1 \log _{10}(<10) \mathrm{ng} / \mathrm{g}$ for toxin $\mathrm{A},<0 \log _{10}(<1) \mathrm{ng} / \mathrm{g}$ for toxin $\mathrm{B}$.

compared with the controls (fig. 4a), the general aspect of the mucosa was the same except for the tips of the villi. By $20 \mathrm{~h}$, the villi appeared to be elongated with deformed tips. At 26 and $30 \mathrm{~h}$ after inoculation, the villi were injured and the tips of villi showed cell shedding (fig. 4b) with extrusion of mucosal cells leading to well-defined lesions.

In the ileum, the effects of inoculation with the
C. difficile strain VPI were the same as the jejunum, with lesions confined to the villi.

Effects of C. difficile strain 786 on the small bowel. At $12 \mathrm{~h}$ after inoculation, only the duodenal samples showed lesions at the tips of the villi. At other sampling times, the aspect of the duodenal villi was normal (fig. 3c). The general aspect of the mucosa and the cellular surface of the villi taken from the jejunum 

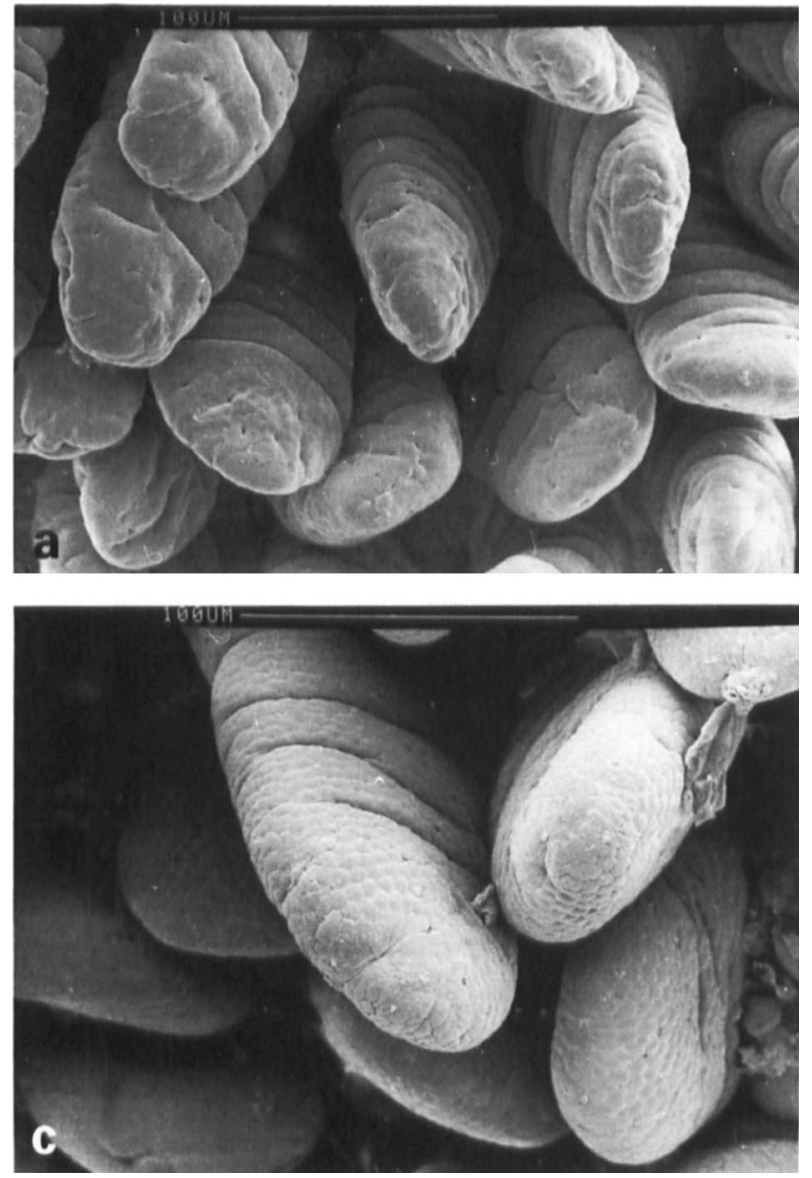

(fig. 4c) and the ileum were identical to those of the controls.

\section{Bacterial count and toxin amounts}

The number of bacteria and the amount of toxins secreted by each strain in the different parts of the gut are presented in the table. $C$. difficile counts in the digestive tract were similar for both strains. As expected for an anaerobic micro-organism, multiplication occurred mainly in the caecum and the colon. This explains why the toxins could not be detected in the upper parts of the digestive tract.

In mice mono-associated with the lethal strain (VPI), the maximal rates of bacterial growth and toxin $\mathrm{A}$ and $\mathrm{B}$ production were reached $12 \mathrm{~h}$ after inoculation and remained stationary thereafter.

In mice mono-associated with the non-lethal strain, the maximal rate of bacterial growth was also reached $12 \mathrm{~h}$ after inoculation, but toxin $\mathrm{B}$ could not be detected before $26 \mathrm{~h}$ and the level was lower than in mice mono-associated with the lethal strain. Toxin A was not detected in any samples from these mice.

\section{Discussion}

The aim of this study was to visualise and localise the modifications of the intestinal mucosa of mice

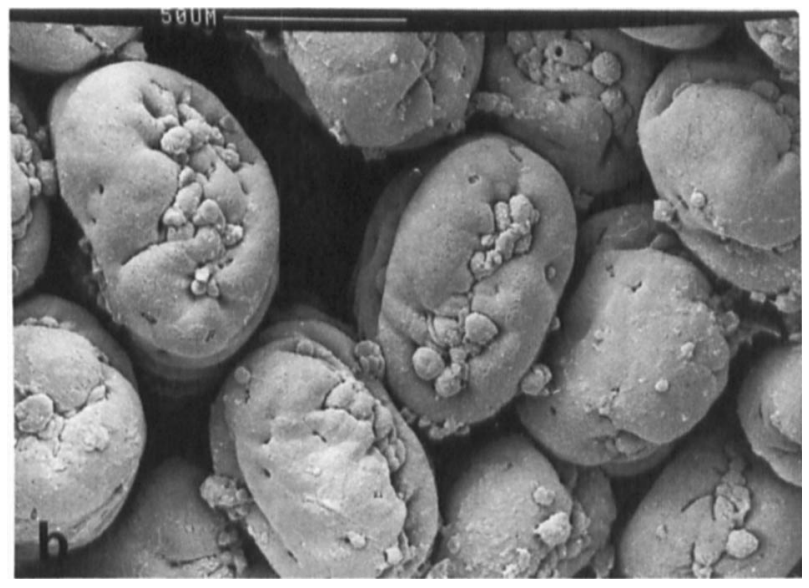

Fig. 4. Scanning electronmicrographs of the jejunum of: a, axenic control mice (bar $=100 \mu \mathrm{m}) ; \mathbf{b}$, mice mono-associated with C. difficile strain VPI, $26 \mathrm{~h}$ after inoculation (bar $=50 \mu \mathrm{m}$ ); $\mathrm{c}$, mice mono-associated with $C$. difficile strain $786,30 \mathrm{~h}$ after inoculation (bar $=100 \mu \mathrm{m})$

mono-associated with either one of two different clinical isolates of $C$. difficile: strain VPI, lethal for animals, and 786, a non-lethal strain. Concomitant with SEM examination of the mouse gut samples, we assayed toxins $\mathrm{A}$ and $\mathrm{B}$ and counted the number of bacteria over a 30 -h period after inoculation. C. difficile strain VPI first exerted its toxic effect in the caecum, where it caused damage within $12 \mathrm{~h}$. Disruption of the cell surface was progressive up to $20 \mathrm{~h}$ and total destruction of the caecal mucosa occurred by $26 \mathrm{~h}$. In the colon, appearance of lesions was delayed, but the damaged aspect of the mucosa was observed at the same time $(26 \mathrm{~h})$ as in the caecum. The early enterocyte separation can probably be explained by the rounding ${ }^{6,11}$ and the cytoskeleton changes ${ }^{7}$ of the cells induced by toxins A and B as observed in tissue culture. The abrasion of the large bowel, which appeared very rapidly (1 day after inoculation), foreshadowed the death of the mice. ${ }^{21,26}$ Since the number of bacteria and the amounts of toxins A and B in the large bowel remained constant at each sampling time, it can be postulated that the lesions induced by the VPI strain were due to the persistence of both toxins in the gut.

Inoculation with $C$. difficile strain 786 did not produce lesions in either the caecum or colon. The presence in the caecum of droplets whose number increased from 12 to $30 \mathrm{~h}$ after inoculation and the "marblebag" appearance of the mucosa appeared to be the only effects of toxin B. Although the com- 
position of these droplets was not studied, their rough and compact aspect, together with the presence of thin filaments attaching them to the brush border, suggested that they were composed of mucus or serum. Since histopathological examinations of the caecum of mice mono-associated with this $C$. difficile strain have shown the presence of inflammatory oedema of the submucosa, ${ }^{21}$ the droplets and the morphological changes in the mucosa observed in our experiments might be due to pressure exerted by the oedema on the surface of the enterocytes. Another explanation for these phenomena (droplets and "marblebag" appearance) is a direct action of toxin B on the caecal mucosa. Indeed, Malorni et al. ${ }^{8}$ have described surface blebbing and morphological changes of culture cells challenged by toxin $\mathbf{B}$.

The rate of appearance of the caecal modifications induced by $C$. difficile strain 786 was quite slow. Furthermore, the amount of toxin B produced by the bacteria was very low $(<1 \mathrm{ng} / \mathrm{g}$ of gut). Since the intensity of the oedema is not dose dependent, ${ }^{21}$ it is possible that larger amounts of this toxin would accelerate the rate of appearance of the droplets and cell shedding. This hypothesis could explain the deleterious effects observed in the caecum when toxins A and B are present simultaneously. Toxin B exerted its activity only in the caecum, suggesting the possibility of a specific receptor for this toxin in the caecum.

In the small intestine, $C$. difficile strain 786 did not induce lesions or modifications of the mucosa except in the duodenum $12 \mathrm{~h}$ after inoculation. This damage was probably due to the fragility of the duodenal villi after passage of the bacteria.

On the other hand, $C$. difficile strain VPI induced morphological changes or lesions in all parts of the small intestine. The kinetics of appearance was progressive and similar, except in the duodenum where

\section{References}

1. Bartlett JG. Clostridium difficile: pseudomembranous colitis and antibiotic-associated diarrhea. In: Gorbach SL (ed) Infectious diarrhea. Boston, Blackwell Scientific Publications. 1986: 157-178.

2. Banno $Y$, Kobayashi $T$, Kono $H$, Watanabe $K$, Ueno $K$, Nozawa T. Biochemical characterization and biologic actions of two toxins (D-1 and D-2) from Clostridium difficile. Rev Infect Dis 1984; 6 Suppl 1: S11-S20.

3. Lyerly DM, Phelps CJ, Toth J, Wilkins TD. Characterization of toxins $\mathbf{A}$ and $\mathbf{B}$ of Clostridium difficile with monoclonal antibodies. Infect Immun 1986; 54: 70-76.

4. Meng XQ, Kamiya S, Yamakawa K, Ogura H, Nakamura S Purification and characterisation of intracellular toxin $A$ of Clostridium difficile. J Med Microbiol 1993; 38: 69-73.

5. Tucker KD, Carrig PE, Wilkins TD. Toxin A of Clostridium difficile is a potent cytotoxin. J Clin Microbiol 1990; 28 869-871.

6. Lima AAM, Lyerly DM, Wilkins TD, Innes DJ, Guerrant RL. Effects of Clostridium difficile toxins $\mathrm{A}$ and $\mathrm{B}$ in rabbit small and large intestine in vivo and on cultured cells in vitro. Infect Immun 1988; 56: 582-588.

7. Fiorentini C, Arancia G, Paradisi S et al. Effects of Clostridium difficile toxins $\mathbf{A}$ and $\mathbf{B}$ on cytoskeleton organization in HEp-2 cells: a comparative morphological study. Toxicon $1989 ; 27$ : $1209-1218$. holes appeared at the tips of the villi at $12 \mathrm{~h}$ but practically disappeared by $20 \mathrm{~h}$. Passage of bacteria could have increased the fragility of the tissue or the mucosa could have been directly attacked by toxins released after lysis of bacteria in the stomach or duodenum. The disappearance of these lesions at $26 \mathrm{~h}$ indicated that this phenomenon was transient. The unusual shapes of the duodenal villi, morphological changes of the mucosa and cell shedding from the jejunal and ileal villi observed at $26 \mathrm{~h}$, were probably caused by bacteria and their toxins. However, neither of the toxins was detected in situ, although bacteria were present. It can be postulated that the mucosal modifications were produced by the release of undetectable amounts of toxins in different parts of the small bowel. It is also conceivable that these mucosal modifications resulted from dissemination of toxins produced by bacteria in the caecum. Indeed, at the 26-h sampling time, the caecum was completely destroyed. Whatever the mechanism, both toxins are necessary.

In conclusion, these results confirm that when the mice were inoculated with $C$. difficile strain VPI that releases toxins $A$ and $B$ in the gut, the intestinal tract showed severe damage that appeared early in the course of the infection. The non-lethal $C$. difficile strain 786 which releases detectable amounts of toxin $B$ alone in the gut was shown to be less harmful. This kinetic study demonstrated that lesions appeared first in the caecum and then in the upper part of the gut. The rapidity of appearance and the severity of the lesions induced by the combination of these toxins, underlines the necessity to treat $C$. difficile infection in man without delay.

We are indebted to Dr S. L. Salhi for critical comments and help in preparing the manuscript and $\mathrm{Mr}$ G. Nabias for technical assistance in SEM examination.

8. Malorni W, Fiorentini C, Paradisi S, Giuliano M, Mastrantonio P, Donelli G. Surface blebbing and cytoskeletal changes induced in vitro by toxin B from Clostridium difficile: an immunochemical and ultrastructural study. Exp $\mathrm{Mol}$ Pathol 1990; 52: 340-356.

9. Meador J, Tweten RK. Purification and characterization of toxin B from Clostridium difficile. Infect Immun 1988; 56: 1708-1714.

10. Mitchell TJ, Ketley JM, Haslam SC et al. Effect of toxin A and B of Clostridium difficile on rabbit ileum and colon. Gut 1986; $27: 78-85$.

11. Sulivan NM, Pellett S, Wilkins TD. Purification and characterization of toxins A and B of Clostridium difficile. Infect Immun 1982; 35: 1032-1040.

12. Arnon SS, Mills DC, Day PA, Henrickson RV, Sullivan NM, Wilkins TD. Rapid death of infant rhesus monkeys injected with Clostridium difficile toxins $\mathrm{A}$ and $\mathrm{B}$ : physiologic and pathologic basis. J Pediatr 1984; 104: 34-40.

13. Libby JM, Jortner BS, Wilkins TD. Effect of the two toxins of Clostridium difficile in antibiotic-associated cecitis in hamsters. Infect Immun 1982; 36: 822-829.

14. Lonnroth I, Lange S. Toxin A of Clostridium difficile: production, purification, and effect in mouse intestine. APMIS 1983; $91: 395-400$

15. Lyerly DM, Saum KE, MacDonald DK, Wilkins TD. Effects of Clostridium difficile toxins given intragastrically to animals. Infect Immun 1985; $47:$ 349-352. 
16. Seddon SV, Hemmingway I, Borriello SP. Hydrolytic enzyme production by Clostridium difficile and its relationship to toxin production and virulence in the hamster model. $J$ Med Microbiol 1990; 31 : 169-174.

17. Davies HA, Boriello SP. Detection of capsule in strains of Clostridium difficile of varying virulence and toxigenicity. Microb Pathog 1990; 9: 141-146.

18. Czuprynski CJ, Johnson WJ, Balish E, Wilkins T. Pseudomembranous colitis in Clostridium difficile-monoassociated rats. Infect Immun 1983; 39: 1368-1376.

19. Wilson KH, Sheagren JN, Freter R, Weatherbee L, Lyerly D. Gnotobiotic models for study of the microbial ecology of Clostridium difficile and Escherichia coli. J Infect Dis 1986; 153: $547-551$.

20. Corthier G, Dubos F, Raibaud P. Ability of two Clostridium difficile strains from man and hare to produce cytotoxin in vitro and in gnotobiotic rodent intestines. Ann Inst Pasteur Microbiol 1986; 137B: 113-121.

21. Vernet A, Corthier G, Dubos-Ramaré F, Parodi AL. Relationship between levels of Clostridium difficile toxin A and $\mathrm{B}$ and cecal lesions in gnotobiotic mice. Infect Immun $1989 ; 57: 2123-2127$.
22. Castex F, Jouvert S, Bastide $M$. Visualization by scanning electron microscopy of the intestinal transit of Saccharomyces boulardii in mice. Bull Soc Fr Mycol Med 1987; 16: 249-256.

23. Corthier G, Dubos F, Raibaud P. Modulation of cytotoxin production by Clostridium difficile in the intestinal tracts of gnotobiotic mice inoculated with various human intestinal bacteria. Appl Environ Microbiol 1985; 49: 250-252.

24. Mahe S, Corthier G, Dubos F. Effect of various diets on toxin production by two strains of Clostridium difficile in gnotobiotic mice. Infect Immun 1987; 55: 1801-1805.

25. Corthier G, Muller MC, Elmer GW, Lucas F, Dubos-Ramaré F. Interrelationships between digestive protolytic activities and production and quantitation of toxins in pseudomembranous colitis induced by Clostridium difficile in gnotobiotic mice. Infect Immun 1989; 57: 3922-3927.

26. Castex F, Corthier G, Jouvert S, Elmer GW, Lucas F, Bastide M. Prevention of Clostridium difficile-induced experimental pseudomembranous colitis by Saccharomyces boulardii: a scanning electron microscopic and microbiological study. $J$ Gen Microbiol 1989; 136: 1086-1089. 